\title{
Versions of Phenomena
}

\section{Sofie Sauzet \\ University College Copenhagen}

\section{DOI: https://doi.org/10.1344/jnmr.v2i2.35899}

This text seeks to rethink the concept of the 'phenomenon' through a diffractive reading of Karen Barad's posthuman theory of performativity: agential realism (Barad, 2007) with my own studies in education (Sauzet, 2021a). The concept of 'phenomenon' comes from the Greek phainómenon, meaning 'that which appears or is seen', and has been the subject of a wide array of writings. I will now briefly introduce a few key-thinkers on the matter, to contextualize how a posthuman approach might differ.

Traditionally, philosophical writings on phenomena are occupied with exploring human experiences, and how these are reflective, mediating, or a part, of phenomena. Immanuel Kant, following Aristotle, conceived of phenomena as denoting that which is experienced empirically by the senses through reflections (Kant, 1770, p. 14). Kant distinguished phenomena from noumena ('things-in-themselves'), separating experiences of, from the reality of, the observed, (or epistemology from ontology) (Wilke, 2013). Edmund Husserl later espoused phenomenology as: "a descriptive theory of the essence of pure transcendental experiences from the phenomenological standpoint." (Husserl, 1964, p. 209). Martin Heidegger later insisted that phenomenology was a fundamental ontology, that hinged on our being-in-the-world ('da-sein') (Heidegger, 1926), and so moved beyond Husserlian and Kantian questions of reflections between objects and subjects, espousing rather that object and subject were inseparable (Horrigan-Kelly, et. al., 2016). ${ }^{1}$ Broadly speaking, phenomenological approaches come together in addressing the problems of appearance (Sokolowski,

\footnotetext{
1 Phenomenology has been developed further still in various directions as existential phenomenology (Jean-Paul Sartre) the phenomenology of the body (Maurice Merleau-Ponty) (Speigelberg \& Biemel, 2017).
} 
2000), and in describing phenomena as experiences of the real or way the world comes into being (Merleau-Ponty, 2012). ${ }^{2}$

In contrast, posthuman theorizing of phenomena rethinks the subject through a decentering of human exceptionalism, defined by an exploration of agency as distributed through a flattened ontology (Alaimo \& Hekman, 2008). Particularly interesting here (and the focus of this paper) is Karen Barad's 'agential realism', in which Barad reads the work of Michel Foucault, Judith Butler, Donna Haraway and Niels Bohr diffractively through one-another in proposing a "relational ontology" (Barad, 2007, p. 130). In agential realism, phenomena are considered as ontological and epistemological entanglements, rather than as separate entities, existing on different planes of existence, whose relationality hinges on human mediation or reflection. And crucially, phenomena are not reproducible, but differentially repeatable. That is: "what matters is not the exact reproduction of the same sequence of events, but the reproduction of a significant pattern despite various differences among instances of the same phenomenon." (Rouse, 2004, p. 143). In this text I draw on agential realism to unfold a post-human consideration of, and analytical strategy for, momentarily stabilizing different versions of the same phenomenon through empirical studies. In doing so, I want to suggest that exploring co-existing versions of a phenomenon, allows for performances of iteration and difference within a phenomenon, as it emerges through time and space. I argue that this approach affords an enactment of the unheeded effects of, and tensions within, phenomena.

Below are fragments of participant observations from 3 different situations, in 3 different schools in Denmark, where I undertook fieldwork from 2017-2019. The fragments concern how social educators ${ }^{3 \prime}$ practices in primary and lower-secondary

\footnotetext{
2 Other traditions, like phenomenalism, are occupied with experiences of phenomena which are thought to be the-thingin-itself (Fissel, 2012). And phenomenography, which explores the: "qualitatively different ways in which people experience, conceptualize, perceive, and understand various aspects of, and various phenomena in the world around them" (Marton, 1986, p. 31).

${ }^{3}$ Social educators are a professional group who work in institutions for children, youth and adults, including: daycares, pre-schools, schools, after-school facilities, special needs institutions, palliative care and with marginalized groups. Their core primary areas of activity are development and care, connected to pedagogical work. Following an extensive reform of the Danish primary and lower secondary schools (2014), social educators became a part of the staff in schools. Before
} 
schools are made possible through different time-space organizings of subjectpositions for them in schools. But the fragments are also examples of a posthuman empirical exploration of situations through which different versions of the same phenomenon - social educators in schools - will be performed.

Version 1: Second period.

The social educator sits on the table placed on one side of the classroom, swinging her legs back and forth. She is looking at the teacher by the blackboard who is instructing the pupils on the content of today's lesson. The room is quiet, there is a concentrated and attentive atmosphere.

Version 2: First period.

The social educator stands by the blackboard, and tries calming the children down, asking them to listen for a minute, so that she can go through the content for today. The room is small. The children's stools almost touch one another, as heavy backpacks dangle from the stools.

Version 3: First period.

The social educator is slouched into the chair, his feet are placed on the desk and his hands are folded behind his head. The children sit on their desks, or walk around, some are tickling each-other, some are talking to each-other. The social educator asks the children if they know what they are supposed to do today. The children reply that they do not know, and that they would prefer doing nothing.

the reform they were mainly employed in after-school centers. Following the reform, they could be employed as coteachers, and, to a lesser extent, teach in the first 4 years of primary school. Following the reform, the number of social educators with tasks in school more than quadrupled. This article draws on fieldwork from 3 different schools, where I followed social educators work lives in schools, which was a new organizational and institutional setting for them (Sauzet, 2019). 


\section{Phenomena}

Agential realism is a post-human theory of performativity, and it is part of what has been called a post-human turn in the humanities and social sciences, which attempts to establish matter and the non-human as active agents in social science analyses, whilst questioning the very material-discursive boundary-making practices that enact 'human' and 'non-humanness' (Barad, 2007, pp. 92-93). From an agential realist stance, the smallest object of analysis is the phenomenon. The phenomenon is defined as the intra-action of the measuring agencies and the object of analysis, and both are considered emergent from, rather than preceding, this intra-action (Barad, 2007, p. 128). Attuning empirical research to this conception of a phenomenon, entails an onto-epistemological off-set, where knowing (epistemology) and being (ontology) are considered as entangled. In this sense agential realism can also be framed as a methodology, as it is involved in the ongoing performance of the world. ${ }^{4}$

As object of analysis: "(...) phenomena are the ontological inseparability of agentially intra-acting "components"'. (Barad, 2007, pp. 308-309). The neologism of intra-action, in contrast to the concept of inter-action, denotes that the agential components, of which phenomena are configured, and their attendant agential qualities are not preconfigured, but rather ontologically indeterminate prior to the practices through which they emerge. As such, the agencies that configure phenomena must be explored to understand what phenomena are made of, and what work they do.

To this point, agential realism proposes an understanding of agency that is not confined to the idea of something that someone has (an attribute); but rather as enactments of iterative changes to practice (Barad, 2007, p. 178, p. 235; 2003, p. 827). This draws analytical attention to how agencies act. Thus, phenomena emerge through a relational ontology, suggesting that identity, agency, and separability is an ongoing performance of the world. Analysing a phenomenon, then, includes both manifesting the emergent agential components and exploring their agential qualities,

\footnotetext{
${ }^{4}$ Methods are part of but not reducible to methodologies. Where methods denote a set of doings/techniques that can be used for producing 'data' (interviewing, surveys etc.), methodology is the entanglements through which research products (i.e., texts) become (Stanley \& Wise, 2013).
} 
as they emerge through intra-actions between the measuring agencies and the object of analysis, which configure phenomena (Sauzet, 2021b).

\section{Co-existing Versions of a Phenomenon}

A phenomenon, like 'social educators in schools', emerges through intra-acting agential components, with attendant agential qualities, and in entanglement with the way we research it. Infused with both iteration and difference, a phenomenon is not just one, but multiple, and a phenomenon might come in different versions. I use the concept of versions, inspired by Annemarie Mol (2002 \& 2012), to suggest how analytical stabilizations perform different configurations of the same phenomenon (Sauzet, 2015, 2021a \& 2021b). Versions co-exist, but differ, and draw forth various aspects of the same phenomenon. Some versions resemble each-other, whilst other versions collide. In co-existing, versions draw attention to the same, different, or even oppositional ways a phenomenon might stabilize in practice. Versions, in my account, are momentary stabilizations of a phenomenon, performed through 'measurement' and analysis, and as they are produced through the same research-apparatus, they can be manifested as co-existing in and across time(s) and space(s) (Barad, 2010). By performing co-existing versions of the same phenomenon, it becomes possible to address the unheeded effects of the complex intra-actions, through which a phenomenon emerges. Performing versions of a phenomenon entails reading, listening, looking, and sensing the empirical material, asking of it: through which intraactively emerging agential components does the phenomenon unfold in practice? In order to answer this question, I now turn to use the observations from the introduction, to unfold 3 versions of the same phenomenon of 'social educators in schools'. In particular, I want to focus on the sections in the above observations marked in bold, which highlight the intra-acting agential components that produce different versions of the same phenomenon.

In version 1 the social educator sits on a table, in the corner, whilst the teacher instructs. The social educator emerges in entanglement between sitting on the table, the swinging of legs, bored or restless, looking at the teacher, as if to gain the same instructions as the children, whom she is expected to help once the teacher has 
finished. Here, a place to sit, becomes a place to wait. And through these intra-actions, the 'social educator in school', emerges as positioned in a place to wait, uninfluential to the content of the lesson, and performed differently to the teacher, both in terms of responsibility and relationality to the children.

Version 2 is an intra-action of the social educator, standing by the blackboard, instructing the children. The blackboard emerges as a place from where to set plans in motion, and standing here, in the exact spot where a teacher once was, affords another agency of the social educator than in the previous version. Thus, the absencepresence (Law, 2004) of a teacher emerges as an agential component, not physically there, but mattering. The room, too, (inadequate in size for this group of children), intraacts in containing and sustaining possibilities for a certain relationality between children and adult, concentration and unquiet.

Version 3 of 'social educators in school' emerges intra-actively through the social educators sitting in front of the blackboard, slouched, feet on the desk and hands behind his head, contesting being an authority. Positioned in this way, the chair and table intra-actively emerges as spaces of contestation. Not knowing the plan, not correcting the children further emerges as a performance of differentiation (a cutting together-and-apart) (Barad, 2007, p. 265) to standard modes of adulting in the classroom.

Versions of a phenomenon do not necessarily, but can, co-exist in the same practices, and agential components of versions do not only dwell in empirical situations. Rather, versions emerge across, and are not defined, nor contained by, Euclidian conceptions of time and space. So, when empirically exploring versions of a phenomenon, that which is seen, heard, sensed, and felt in a situation, is intra-actively informed by previous (and future) times and spaces, effectively affecting how a phenomenon emerges as 'haunted' by non-enunciated, not-present, non-visible agencies (Barad, 2010). Across different times and spaces, and different multi-sensory empirical materials, analysing versions of a phenomenon thus includes an attunement to what is present, and to what is absent-present (Law, 2004). A phenomenon is thus 
entangled across times and spaces, and in an agential realist account, this entanglement is not mysterious, because there are no different planes of existence. There are just entanglements (Barad, 2007, 316-317).

Attuning to versions of a phenomenon is a process of researching presences, absences, emergences, differentiations, cuts, and the unheeded mundane materialdiscursive practices of, in my case, education. It's assembling the unassimilable, and allowing research to emerge in mess (Law, 2004). 'Social educators in schools', can accordingly be versions 1, 2 and 3 . In some schools they are mostly one, or maybe two, but in other schools they are all three, and more. What unites versions, is that they emerge in intra-action with the way they are 'measured', and how schools organize subject positions for social educators. But versions also differ. Differences include being alone with children in a teaching situation, being with a teacher with/without prior time for preparation or being alone with children without insight into their previous or future activities. By following and analysing a phenomenon, multiple coexisting versions can be performed, and they manifest the complexities, tensions and contradictions of phenomena.

From a posthuman perspective, performing versions of a phenomenon, re-works questions of representation, human exceptionalism, and subject/object distinctions, traditionally attached to the concept of the phenomenon, as argued in the introduction. So, analysis is not of - or on - the world, but with - and in - the world. This consideration substitutes problematic binaries inherent within traditional modes of representation and reflection, with concerns for performativity and non-representationalism, through the tenets of an onto-epistemological offset. A posthuman approach, then, simultaneously situates and decenters human experiences of phenomena, and considers agency as emergent and distributed across human/nonhuman forces, whilst performing the hauntological relations of phenomena across times and spaces.

Performing versions of a phenomenon makes it possible to draw attention to the unheeded effects of the doings of a phenomenon. Both its iterations, differences, tensions, multiplicities or extendings (Sauzet, 2021a). My specific phenomenon of study, 'social educators in schools', emerges as extended between different, co- 
existing, mutually incompatible, versions of performing appropriate and permitted forms of behaviour in school. In conclusion, perhaps drawing attention to the unheeded effects of co-existing, multiple, versions of a phenomenon, can unfold as a form of critique applicable not to individuals, but to the intra-actions that afford and effect the performances of different versions of phenomena.

\section{Bibliography}

Alaimo, Stacy \& Susan Hekman (2008). Material Feminisms. Bloomington: Indiana University Press.

Barad, Karen (2007). Meeting the Universe Halfway: Quantum Physics and the Entanglement of Matter and Meaning. Duke University Press.

Barad, Karen (2010). Quantum Entanglements and Hauntological Relations of Inheritance: Dis/continuities, SpaceTime Enfoldings, and Justice-to-Come. Derrida today, 3(2): 240-268. http://doi.org/10.3366/E1754850010000813

Fisette, Denis (2012). Phenomenology and Phenomenalism: Ernst Mach and the Genesis of Husserl's phenomenology. Axiomathes, (22): 53-74. http://doi.org/10.1007/s10516-011-9159-7

Horrigan-Kelly, Marcella, Millar, Michelle \& Dowling, Maura (2016). Understanding the Key Tenets of Heidegger's Philosophy for Interpretive Phenomenological Research. International Journal of Qualitative Methods: 1-8. https://doi.org/10.1177/1609406916680634

Heidegger, Martin (1962/1926). Being and Time (John Macquarrie \& Edward Robinson, Trans.). Oxford, UK: Blackwell Publishers.

Husserl, Edmund (1963/1913). Ideas: A General Introduction to Pure Phenomenology. Trans. William, R. Boyce Gibson. Oxon, UK: Collier Books.

Kant, Immanuel (1770). Dissertation on the form and principles of the sensible and intelligible world. Retrieved at:

https://en.wikisource.org/wiki/Kant\%27s_Inaugural_Dissertation_of_1770

Law, John (2004). After Method. Mess in Social Science Research. Oxon, UK: Routledge.

Marton, F. (1986). Phenomenography-A Research Approach to Investigating Different Understandings of Reality. Journal of Thought, 21(3), 28-49. Retrieved July 2, 2021, from http://www.jstor.org/stable/42589189 
Merleau-Ponty, Maurice (2012). Phenomenology of perception (Donald, A. Landes, Trans.). New York: Routledge.

Mol, Annemarie (2002). The body multiple: ontology in medical practice, Durham, UK: Duke University Press.

Mol, Annemarie (2012). Layers or Versions? Human Bodies and the Love of Bitterness. Routledge Handbook of Body Studies. B. S. Turner. London: Routledge, 119-159

Rouse, Joseph (2004). Barad's Feminist Naturalism. Hypathia, 19(1): 142-161. https://doi.org/10.1111/j.1527-2001.2004.tb01272.x

Sauzet, Sofie (2015). Versioner - diffraktive analyser af tværprofessionalismens tilblivelse som fænomen i professionshøjskolen. Ph.d. Dissertation. DPU. Århus University.

Sauzet, Sofie (2019). Pædagogers faglighed i skolen - udspændtheder i litteratur og praksis. Samfundslitteratur.

Sauzet, Sofie (2021a). What "what we know" does - a posthuman review methodology. Reconceptualizing Educational Research Methodology. Vol. 12, No. 1 (2021) https://doi.org/10.7577/rerm.4246

Sauzet, Sofie (2021b, forthcoming). "Interdisciplinarity in the University Colleges: An interprofessional responsibility?". Configurations of interdisciplinarity Across the educational System. Danish experiences in a Global Educational Space. (Edt.) Lindvig, K., Ryberg, M., Sauzet, S \& Øland, T. Routledge.

Spiegelberg, Herbert \& Walter Biemel (2017). Phenomenology. Encyclopedia Britannica. Retrieved at: https://www.britannica.com/topic/phenomenology

Stanley, Liz \& Sue Wise (2013). Method, methodology and epistemology in feminist research processes". Feminist praxis. Research, Theory and Epistemology in Feminist Sociology. Routledge.

Sokolowski, Robert (2007). Introduction to phenomenology. Uk. Cambridge University Press.

Wilke, Sabine (2013). Anthropocenic Poetics: Ethics and Aesthetics in a New Geological Age. RCC Perspectives, No. 3, Anthropocene: Envisioning the Future of the Age of Humans (2013), pp. 67-74. Rachel Carson Center Stable. http://doi.org/10.5282/rcc/6215 


\section{Author Information}

\section{Sofie Sauzet (sosa@kp.dk)}

Sofie Sauzet, PhD, is an Associate Professor in Educational Research at University College Copenhagen. She works from posthuman theories in studying how the practices of professionals are sustained and made recognisable as relevant and competent within different organizations of professional work, and their related knowledge-political spaces of possibility. 